\title{
Students' Level of Anxiety Towards Learning English as a Foreign Language: Students' Perspectives
}

\begin{abstract}
Amal Shehadeh AlNatour
Yarmouk University, Irbid, Jordan

The purpose of this paper is to study the level of anxiety among Yarmouk University students in Jordan/Irbid and to investigate if there are any statistically significant differences in anxiety level attributed to gender. The sample of the study consisted of 280 students (150 females and 130 males) who were enrolled in English Language service courses Eng 99, Eng 101 in the second semester 2016/2017. The researcher adopted a scale to collect data and to achieve the goals of the study. The instrument had 33 items on required multiple choice answers with a five-point Likert scale. The results show that the participants generally had a feeling of anxiety in learning English. They experienced Test Anxiety and Fear of Negative Evaluation. Moreover, the results show that there are statistically significant differences in anxiety level attributed to gender in favor of male students. The researcher recommends conducting further studies that focus on developing anxiety free classroom environment during teaching English as a foreign or second language.
\end{abstract}

Keywords: anxiety, English language learning, English 101, teaching foreign language, students' perspectives

\section{Introduction}

Language teachers, including the researcher, have noticed on many different occasions that students who are trying out to acquire and produce a foreign language show apprehension and discomfort especially when they are asked to speak in class and during tests. Foreign Language Classroom Anxiety is an educational phenomenon that has a growing attention among researchers and is broadly recognized for its considerable impact on learners. Gardner (1985) showed high correlation between the anxiety and the proficiency.

Besides, Campbell and Ortiz (1991) stated that among university students, the levels of anxiety learning foreign language was very high and concluded that $50 \%$ of all language learning students have got through unfavourable language anxiety. According to LIU (2007) and Ohata (2005), a foreign language class, for many students, can be more anxiety-evoking than any other course they take and anxious learners show less readiness to take part and have lower performance than non-anxious ones (Horwitz, 2001; Tsiplakides \& Keramida, 2009). Moreover, Horwitz, Tallon, and LUO (2010) argued that about a third of language students go through foreign language anxiety (mild anxiety and debilitating levels of anxiety). In addition, Elkhafaifi (2005) showed that advanced levels of anxiety have very big effects on motivation and achievement that FL anxiety can discourage students from following up academic or professional careers.

Because anxiety is one of the internal components of second language learners that might obstruct performance and achievement, a big number of research starting from the mid 1970s have investigated 
classroom anxiety like Brown (1973), Chastain (1975), and Scovel (1978).

As a complex psychological term, Davu and Palladino (cited in Kelly, 2002) have defined anxiety as "a general feeling of apprehension including hyper-vigilance, increased sympathetic nervous system activity, and difficulty concentrating” (p. 54). Also, E. -K. Horwitz, M. -B. Horwitz, and Cope (1986), Rachman (1998), Brown (2000), and Horwitz (2009) associated anxiety with tension, fear, frustration, apprehension, uneasiness, insecurity uneasiness, insecurity, and nervousness.

Furthermore, MacIntyre (1995) referred anxiety to a sentimental situation which may have positive and negative effects and that enhances and assists or distresses and hinders language learning. Moreover, Oxford (1999a) showed that anxiety has a negative type "debilitating anxiety" and a positive one. Debilitating anxiety harms learners' performance like hindering them from taking part in the activities or not applying the language in general social direct positions while positive anxiety may be considered as useful in enhancing students' level of attention.

According to some researchers, there are different types of anxiety, such as trait anxiety and state (situational) anxiety. Trait anxiety is the aptness of a learner to be tense despite any specific condition while state anxiety is the stress and uneasiness in response to some outside stimulus like communication anxiety, which may occur when learners commune (MacIntyre \& Gardner, 1989; Daly, 1991; Horwitz, 2000). Another type of anxiety is panic of negative evaluation that appears when learners are very concerned about how others assist their levels (Horwitz et al., 1986). According to Spielmann and Radnofsky (2001), other anxieties may be observed in classrooms, such as cognitive tension and affective tension. Cognitive tension appears when students' assumptions are not on line with the core and arrangements of the material included in the course. Affective tension appears when the learners show disagreement when communicating with their peers and teacher. Test anxiety which is defined by Horwitz et al. (1986) as anxiety of low level of production on exams, and subject anxieties (fear related to the four skills of language) are other classroom anxieties (Young, 1990; Oh, 1992; Vogely, 1998; CHENG, Horwitz, \& Schallert, 1999; Saito, Horwitz, \& Garza, 1999; VanPatten \& Glass, 1999; Arnold, 2000; Sellers, 2000; Matsuda \& Gobel, 2001).

Different areas of research have investigated the causes of foreign language learning anxiety. For example Jackson (2002), Oxford (1999a), Spielmann and Radnofsky (2001), and Young, (1991) investigated the situational variables (course activities, course level, course organization, and instructor behavior). Moreover, Dewaele (2002), Gregersen and Horwitz, (2002), Oxford (1999b), Bailey, Daley, and Onwuegbuzie (1999), Ehrman and Oxford (1995), Gardner et al (1992) examined learners' variables (age, beliefs, gender, learning styles, and personality factors among others). In contrast, Ganschow, Javorsky, Sparks, Skinner, Anderson, and Patton (1994) claimed that the native language ability and language learning aptitude of the learner are the problems of foreign language learning rather than anxiety or other affective factors.

Bailey et al (1999) and Oxford (1999a) associated foreign language learning anxiety with negative physical, psychological, or social outcomes which lead to poor performance and low achievement. Physical outcomes may be manifested as rapid heartbeat, dry mouth, excessive perspiration, and muscle tension. Social symptoms include inappropriate silence, unwillingness to participate, withdrawal from the course, and absenteeism. Psychological outcomes may be manifested as embarrassment, fear, going blank, feelings of helplessness, and poor memory recall and retention among others. 


\section{Statement of the Problem}

Because language is very important in expressing ourselves, communicating with people, planning our future, and exchanging ideas, it is very important to recognize what hinders language learning. In light of the increasing number of students learning English around the world, this study is an attempt not only to address the lack of research regarding Jordanian universities, but also to add empirical evidence to how learner variables, such as anxiety, affect the learning of English.

\section{Questions of the Study}

This study attempts to answer the following questions:

(1) What are the causes of language learning anxiety of YU (Yarmouk University) students who are taking Eng 101 as an obligatory course in the second semester 2016/2017?

(2) Are there any statistically significant differences at $\alpha=0.05$ in anxiety level of students who are taking Eng 101 and Eng 99 as an obligatory course in the second semester 2016/2017 attributed to gender?

\section{Purpose of the Study}

The purpose of the study is to investigate the level of anxiety among YU students and to investigate if there are any statistically significant differences in anxiety level attributed to gender.

\section{Significance of the Study}

Since there is a crucial need to learn English as an international language which opens the whole world of technology in front of us, it is very important to explore anxiety as a main reason of hindering language learning. The outcomes of this study are useful in that they might help to build a greater understanding of the impact of foreign language anxiety on language learning within Jordan. Furthermore, the results may enrich the instructors' awareness towards their role in decreasing language learning anxiety. Moreover, this study should open venues for further research in language learning anxiety as a problem in pedagogy and how it hinders learners' achievements.

\section{Methods and Procedures}

\section{Method of the Study}

The researcher uses the descriptive analytical method in order to analyze the results of the study. This method studies a certain issue or a phenomenon in order to collect information that answers the questions of the study without any bias from the researcher.

\section{Population and Sample of the Study}

The population of the study consisted of all students at Yarmouk University who were enrolled in the English Language service courses Eng 99, Eng 101. The sample was 280 students (150 females and 130 males) who were chosen randomly and were taking English Language service courses Eng 99, Eng 101 at YU in the second semester 2016/2017 as distributed in Table 1. 
Table 1

Distribution of the Study Sample According to the Independent Variables (IV) of the Study

\begin{tabular}{llll}
\hline Independent variable & Levels & Frequency at level of IV & Total \\
\hline \multirow{2}{*}{ Gender } & Female & 150 & \multirow{2}{*}{280} \\
& Male & 130 & \\
\hline
\end{tabular}

\section{Instrument of the Study}

In order to achieve the goals of the study, the researcher adopted Horwitz et al (1986) scale which has a high validity and reliability. Besides, it is flexible so it can be applied on the Jordanian environment. The instrument had 33 multiple choice answers. It has a five-point Likert scale with values 1-5 that ranges from strongly disagree to strongly agree. The first three items measured foreign language anxiety relating to as: test anxiety $(2,8,10,19$, and 21), fear of negative evaluation $(3,7,13,15,20,23,25,31$, and 33), and communication anxiety $(1,9,14,18,24,27,29$, and 32) and they were adopted from Horwitz et al (1986) while the fourth item which is related to English classroom anxiety $(4,5,6,11,12,16,17,22,26,28$, and 30) was employed by some researchers, such as ZHAO (2007).

\section{Procedures of the Study}

The researcher applies the following procedures in order to collect data:

(1) Determining the population of the study and the sample;

(2) Adopting Horwitz et al (1986) scale as the instrument of the study;

(3) Distributing the instrument on the sample and collecting the data;

(4) Analyzing the results in light of the questions of the study;

(5) Drawing conclusions and recommendations according to the results of the study.

\section{Limitations of the Study}

This study is limited to YU students who were taking Eng 101 and Eng 99 in the second semester2016/2017. Therefore, the generalization of the results of the study is applicable to similar populations only.

\section{Literature Review}

A great deal of foreign language (FL) learning research papers since the 1970s have been conducted to investigate the reasons that hinder foreign language learning with respect to specific classroom activities, such as speaking, reading, writing, and listening. All of these studies provided valuable insights into the area of foreign language anxiety. For example CHENG et al. (1999) investigated the relationship between FL classroom anxiety and their associations with FL speaking and writing achievement. A questionnaire was distributed to 433 Taiwanese English majors. The results showed that classroom anxiety in foreign language contexts is the most common source of anxiety about learning a FL especially in issues related to speaking anxiety factor, while FL writing anxiety is a more definite language skill anxiety. Moreover, the researchers revealed that little self-confidence appeared to be a crucial element of both anxiety forms.

Moreover, LIU (2007) conducted a study to examine anxiety in oral English classrooms in a Chinese university. The sample consisted of 27 college students responding to a survey (FLCAS: Foreign Language Classroom Anxiety Survey) and keeping reflective journals. The researcher found out that anxiety was experienced by many students while speaking English in class especially when making presentations at the front. Their anxiety was a result of the lack of vocabulary, low English proficiency, and memory disassociation. 
In addition, Gai and Yang (2010) conducted a study to find out the constituents that affect students' anxiety to spoken English and set some results and suggestions to help students to enhance their level in spoken English. The researchers used a survey with 82 Chinese college students. The results approved that the participants who had higher anxiety also had the lower spoken English ability.

Furthermore, Kuru Gonen (2005) tried to reveal the reasons of Turkish EFL students' anxiety while they were reading in the target language. She asked the students to keep diaries for two months on a weekly basis and then interviewed them. The results showed that there were three main sources of FL reading anxiety in a Turkish EFL context.

Other research papers have been conducted to investigate anxiety as a main factor that hinder foreign language learning and tried to find out the source of such anxiety. $\mathrm{Na}$ (2007) conducted a study on Chinese high school students. The sample consisted of 115 students. The results of the study showed that the participants had high anxiety in learning the English language and that male students had higher anxiety in learning English than female ones. Regarding the sources of FL anxiety, Aydin (1999) tried to find out the sources of FL anxiety that Turkish students experience in speaking and writing. The participants were 36 Turkish first-year EFL students. A questionnaire and interviews were used. The results of the study showed that students with high anxiety level were disappointed because of not being able to interact in the FL which led them to encounter FL speaking anxiety, which also decreased their trust in themselves. Students were worried also of being assessed in a negative way by their peers in the classroom who were better than them. So, Turkish EFL students mostly avoided speaking and preferred to remain silent.

Another study done by Kitano (2001) investigated Japanese college learners' two sources of anxiety in oral practice: (1) single student's uneasiness of negative evaluation, and (2) student's self-awareness ability of speaking. The participants of the study were 212 students in Japanese courses at two universities. A survey of 70-item multiple-choice was used. The researcher used correlation and regression to analyze the data. The results showed that student's fear of negative evaluation was stronger while an individual anxiety was higher. Moreover, the anxiety of a male student became higher as he perceived himself less competent.

Furthermore, Pappamihiel (2002) examined language anxiety among Mexican students who immigrated and attended school in the US. Participants were 178 middle-school students. The researcher found out that interaction with Mexican students increased their levels of anxiety and strategies like avoidance were used to decrease anxiety.

Moreover, Williams and Andrade (2008) conducted a study on Japanese students. The sample of the study consisted of 243 Japanese students in 31 English conversation classes at four universities in Japan. The results of the study showed that language anxiety was related to the results and action stages of the language learning activity. Moreover, students' anxieties were caused by their teachers and classmates.

In addition, Subaşı (2010) conducted a study that investigated two possible sources of the anxiety of Turkish students of English in oral practice at Anadolu University. The sample of the study consisted of 55 first year learners. The findings showed a positive association between an individual's anxiety level and his/her fear of negative evaluation. In addition, the analysis revealed the some sources of the students' anxiety in oral practice like: teachers' manners, teaching procedures, personal reasons, and previous experience.

English classroom anxiety and test anxiety are two main types of students' anxiety according to some researchers. Andrade and Williams (2009) investigated learning anxiety on Japanese university students. The sample consisted of 243 Japanese learners at 31 four-year universities in Japan. The results showed that anxiety 
impacted $75 \%$ of the participants during English lessons.

We can also see that Petridou and Williams (2007) conducted a study to analyze the effect of test anxiety on person aberrance. The results showed that higher-scoring pupils and second-language learners are significantly more often aberrant.

Moreover, Aydin (2013) investigated the level of test anxiety among young learners of English and the relationship between test anxiety and grade, gender, age, economic background, and achievement level. The sample of the study consisted of 477 EFL learners from five elementary schools. To collect the data, the researcher used a questionnaire and the Test Anxiety Scale. The findings indicated that the participants had a low level of test anxiety.

Foreign language anxiety has relations and is associated with some factors like perfectionism, multiple intelligences, and learner attitudes. Researchers highlighted such factors as affecting students' performance during English lessons. For example, Gregersen and Horwitz (2002) conducted a study to find out the relationship between FL anxiety and perfectionism. The sample of the study was eight students. Half of the sample was the most anxious students and the other half was the least anxious. The students were interviewed and by examining their reactions to their actual oral performance and analyzing their audio tapes, it was found that anxious learners vary in their individual presentation, uneasiness of evaluation, procrastination, and fear of mistakes than non-anxious ones.

LIU and CHEN (2013) also investigated language anxiety in young EFL learners and how it is associated to multiple intelligences and learner attitudes. The sample consisted of 216 fifth and sixth grade learners from two elementary schools. The results showed that the learners went through language anxiety which indicated in two major components: little confidence in speaking ability and general worry over language class performance.

In order to find solutions for problems that are caused by anxiety through FL lesson, some research papers were conducted. For example, Tsiplakides and Keramida (2009) conducted a study to investigate the characteristics of anxious students and to provide instructors with methods to deal with anxiety derived from students' fear and uneasiness of negative evaluation from other students and attitude of weak capacities. The participants were 15 Greek students. The results showed that English language speaking anxiety has appeared among six students as a consequence of fear of negative evaluation from other students and their low self-confidence of their abilities.

\section{Results and Discussions}

\section{First Research Question}

What are the causes of language learning anxiety of YU students who were taking Eng 101 and Eng 99 as an obligatory English course in the first semester 2016/2017?

To answer the first research question, a quantitative analysis of the collected data was made. Moreover, a descriptive statistical analysis was used including means and standard deviations to analyze the data. Mean (M) described the overall anxiety factors of the participants while Standard Deviation (SD) measured the variability of responses as shown in Table 2. 
Table 2

Means and Standard Deviations of English Language Anxieties Experienced by Students at Yarmouk University

\begin{tabular}{lll}
\hline Anxiety type & $\mathrm{M}$ & $\mathrm{SD}$ \\
\hline Communication anxiety & 3.00 & 0.35 \\
Fear of negative evaluation & 3.17 & 0.71 \\
Test anxiety & 3.19 & 0.30 \\
Anxiety in the English classroom & 2.92 & 0.44 \\
\hline
\end{tabular}

Table 2 shows that the participants generally had a feeling of anxiety in learning English language. Moreover, they experienced test anxiety $(M=3.19)$ and fear of negative evaluation $(M=3.17)$. Students felt very frightened of taking tests. They got worried of making mistakes and feared the negative consequences of having low scores. Bad grades may affect their self-confidence, their confidence on their abilities, their peers' feedback, as well as their teachers'. This result is in line with Cubukcu (2007) who claimed that test anxiety creates negative motivation in learning and described it as an unpleasant feeling that has behavioral and physiological occurrence. Moreover, it is in line with Ohata (2005) who stated that test-taking situations would make students anxious about the bad consequences of having a bad score which may cause psychological stresses like feeling inferior to others or the fear of losing self-confidence.

The results also revealed that the participants experienced anxiety due to fear of negative evaluation from their peers and their teachers, too. Participants had negative affective experience when they were learning the language which made them feel anxious and worried if being called, corrected, or evaluated by their teacher or peers. This may due to certain type of activities that had to be done by students in front of the class which may make them feel embarrassed to talk or participate fearing of making mistakes. Young (1991) and Palacios (1998) stated that there are some classroom activities that create and increase students' anxiety, such as oral production activities which make students speak in front of the class.

\section{Second Research Question}

Are there any statistically significant differences at $\alpha=0.05$ in anxiety level of students who were taking Eng 101 and 99 as an obligatory course in the second semester 2016/2017 attributed to gender?

The researcher computed the means and standard deviations for males and females to answer the second question. The results are shown in Table 3.

Table 3

Means and Standard Deviations of the Students’ Anxiety According to Their Gender

\begin{tabular}{llll}
\hline Independent variable & Levels & Mean & Std. Dev. \\
\hline \multirow{2}{*}{ Gender } & Female & 2.747 & 0.46 \\
& Male & 2.789 & 0.40 \\
\hline
\end{tabular}

Table 3 shows that male students have higher anxiety (2.789) than their female counterparts (2.747). This may refer to the fact that foreign language learning anxiety might be affected by some socio-cultural aspect which may also affect male students' way of thinking.

In the Arab world, males used to be seen as dominant figures who are known for their manhood and strength. Therefore, it is not easy for them to shake this stereotyping image about them, so they feel anxious about participating, making mistakes, or be corrected in front of their male and female classmates. 
The result of this question is in line with Andrade and Williams (2009) and Na (2007) who indicated that male participants have higher anxiety in learning English than female ones. Despite the fact that SHI and LIU (2006) concluded no significant gender difference in foreign language anxiety, they found that male participants had high foreign language reading anxiety than female ones.

However, Abu-Rabia (2004) and Bensoussan and Zeidner (1989) are not in line with the researcher's result. They found that female students experienced more foreign language anxiety than male ones.

\section{Conclusion and Recommendations}

Foreign language learning anxiety has appealed many researchers to study this phenomenon as it impacts language learners. The results of the current study show that the students are generally anxious during English lessons, worried of being negatively evaluated and fearful about tests. This may refer to their low self-esteem and competitiveness. They feel very frightened of taking tests, making mistakes, and getting negative consequences of having low scores which may refer to other psychological stresses like the fear of losing self-confidence or feeling inferior to others.

It is also shown that male participants were more anxious than their female counterparts. This may refer to some socio-cultural beliefs about males of being the figures who are strong and have no slips.

As a result of the current study, the researcher suggests that there should be more research papers that find solutions for students' anxiety by concentrating on issues like learning community and a supportive classroom atmosphere, teacher-students relations, teachers' indirect rather than direct correction, teachers' immediacy (humor, eye contact, positive gestures), praising for students in front of their peers and fostering students' motivation.

\section{References}

Abu-Rabia, S. (2004). Teachers' role, learners' gender differences, and FL anxiety among seventh-grade students studying English as a FL. Educational Psychology, 24(5), 711-721.

Aly, J. (1991). Understanding communication apprehension: An introduction for language educators. In E. K. Horwitz and D. J. Young (Eds.), Language anxiety: From theory and research to classroom implications (pp. 3-13). Englewood Cliffs, NJ: Prentice Hall.

Andrade, M., \& Williams, K. (2009). Foreign language learning anxiety in Japanese EFL university classes: Physical, emotional, expressive, and verbal reactions. Sophia Junior College Faculty Journal, 29, 1-24.

Arnold, J (Ed.). (1999). Affect in language learning. Cambridge, UK: Cambridge University Press.

Arnold, J. (2000). Seeing through listening comprehension exam anxiety. TESOL Quarterly, 34(4), 777-786.

Aydin, B. (1999). A study of the sources of foreign language classroom anxiety in speaking and writing classes (Unpublished doctoral dissertation, Anadolu University, Eskişehir, Turkey).

Aydin, S. (2013). Factors affecting the level of test anxiety among EFL learners at elementary schools. E-international Journal of Educational Research, 4(1), 63-81.

Bailey, P., Daley, C. E., \& Onwuegbuzie, A. J. (1999). Foreign language anxiety and learning style. Foreign Language Annals, 32(1), 63-76.

Bensoussan, M., \& Zeidner, M. (1989). Anxiety and achievement in a multicultural situation: The oral testing of advanced reading comprehension. Assessment and Evaluation in Higher Education, 14(1), 40-54.

Brown, H. D. (1973). Affective variables in second language acquisition. Language Learning, 23, 231-244.

Brown, H. D. (2000). Principles of language learning and teaching. New York: Pearson Education.

Campbell, C. M., \& Ortiz, J. A. (1991). Helping students overcome foreign language anxiety: A foreign language anxiety workshop. In E. K. Horwitz and D. J. Young (Eds.), Language anxiety: From theory and research to classroom implications (pp. 153-168). Englewood Cliffs, NJ: Prentice-Hall.

Chastain, K. (1975). Affective and ability factors in second language acquisition. Language Learning, 25(1), 153-161. 
CHENG, Y., Horwitz, E. K., \& Schallert, D. L. (1999). Language anxiety: Differentiating writing and speaking components. Language Learning, 49(3), 417-446.

Cubukcu, F. (2007). Foreign language anxiety. Iranian Journal of Language Studies, 1(2), 133-142.

Daly, J. A. (1991). Understanding communication apprehension: An introduction for language educators. In E. K. Horwitz and D. J. Young (Eds.), Language anxiety: From theory and research to classroom implications (pp. 3-13). Englewood Cliffs, NJ: Prentice Hall.

Dewaele, J. (2002). Psychological and socio-demographic correlates of communicative anxiety L2 and L3 production. International Journal of Bilingualism, 6(1), 23-38.

Ehrman, M. E., \& Oxford, R. L. (1995). Cognition plus: Correlates of language learning success. The Modern Language Journal, 79(1), 67-89.

Elkhafaifi, H. (2005). Listening comprehension and anxiety in the Arabic language classroom. The Modern Language Journal, 89(2), 206-220.

Gai, F. P., \& Yang, D. (2010). A study on college students' anxiety to spoken English. Canadian Social Science, 6(2), 95-101.

Ganschow, L., Javorsky, J., Sparks, R. L., Skinner, S., Anderson, R., \& Patton, J. (1994). Differences in language performance among high, average, and low-anxious college foreign language learners. The Modern Language Journal, 78(1), 41-55.

Gardner, R. C. (1985). Social psychology and second language learning: The role of attitudes and motivation. London: Edward Arnold.

Gardner, R. C., Day, J. B., \& McIntyre, P. D. (1992). Integrative motivation, induced anxiety, and language learning in a controlled environment. Studies in Second Language Acquisition, 14(2), 197-214.

Gregersen, T., \& Horwitz, E. K. (2002). Language learning and perfectionism: Anxious and non-anxious language learners' reactions to their own oral performance. The Modern Language Journal, 86, 562-570.

Horwitz, E. K. (1986). Preliminary evidence for the reliability and validity of a foreign language anxiety scale. TESOL Quarterly, 20(3), 559-562.

Horwitz, E. K. (2000). It ain't over til it's over: On foreign language anxiety, first language deficits, and the confounding of variables. Modern Language Journal, 84, 256-259.

Horwitz, E. K. (2001). Language anxiety and achievement. Annual Review of Applied Linguistics, 21, 112-126.

Horwitz, E. K. (2009). Cultural identity and language anxiety: How self-concept and cultural expectations interact with performance in a second language. In P. CHENG and J. X. YAN (Eds.), Cultural identity and language anxiety (pp. 57-69). Guanxi, China: Guangxi Normal University Press.

Horwitz, E. K., \& Young, D. (Eds.). (1991). Language anxiety: From theory and research to classroom implications. Englewood Cliffs, NJ: Prentice Hall.

Horwitz, E. K., Horwitz, M. B., \& Cope, J. A. (1986). Foreign language classroom anxiety. The Modern Language Journal, 70(2), 125-132.

Horwitz, E. K., Tallon, M., \& LUO, H. (2010). Foreign language anxiety. In J. C. Cassady (Ed.), Anxiety in schools: The causes, consequences, and solutions for academic anxieties (pp. 95-115). New York, NY: Peter Lang.

Jackson, J. (2002). Reticence in second language case discussions: Anxiety and aspirations. System, 30(1), 65-84.

Kelly ,W. E. (2002). Anxiety and the prediction of task duration: A preliminary analysis. The Journal of Psychology, 136(1), 53-58.

Kitano, K. (2001). Anxiety in the college Japanese language classroom. The Modern Language Journal, 85, 549-566.

Kuru Gonen, S. I. (2005). The sources of foreign language reading anxiety of students in a Turkish EFL context (M.A. thesis dissertation, Anadolu University, Eskisehir).

LIU, H., \& CHEN, T. (2013). Foreign language anxiety in young learners: How it relates to multiple intelligences, learner attitudes, and perceived competence. Journal of Language Teaching and Research, 4(5), 932-938.

LIU, M. (2007). Anxiety in oral English classrooms: A case study in China. Indonesian Journal of English Language Teaching, 3(1), 119-137.

MacIntyre, P. D. (1995). How does anxiety affect second language learning? A reply to Sparks and Ganschow. The Modern Language Journal, 79(1), 90-99.

MacIntyre, P. D., \& Gardner, R. C. (1989). Anxiety and second language learning: Toward a theoretical clarification. Language Learning, 39(2), 251-275.

Matsuda, S., \& Gobel, P. (2001). Quiet apprehension: Reading and classroom anxieties. JALT Journal, 23(1-2), 227-247.

Na, Z. (2007). A study of high school students' English learning anxiety. The Asian EFL Journal, 9(3), 22-34. 
Oh, J. (1992). The Effects of L2 reading assessment methods on anxiety level. TESOL Quarterly, 26(1), 172-176.

Ohata, K. (2005). Potential sources of anxiety for Japanese learners of English: Preliminary case of interviews with five Japanese college students in the US. TESL-EJ, 9(3), 2-23.

Oxford, R. (1999a). Anxiety and the language learner: New insights (pp. 58-67). In J. Arnold (Ed.), Affect in language learning. Cambridge, UK: Cambridge University Press.

Oxford, R. (1999b). "Style wars" as a source of anxiety in language classrooms. In D. J. Young (Ed.), Affect in foreign language and second language learning: A practical guide to creating a low-anxiety classroom atmosphere (pp. 216-237). Boston: McGraw-Hill College.

Palacios, L. M. (1998). Foreign language anxiety and classroom environment: A study of Spanish university students (Unpublished doctoral dissertation, The University of Texas, Austin).

Pappamihiel, N. E. (2002). English as a second language students and English language anxiety: Issues in the mainstream classroom. Research in the Teaching of English, 36, 327-355.

Petridou, A., \& Williams, J. (2007). Accounting for aberrant test response patterns using multilevel models. Journal of Educational Measurement, 44(3), 227-247.

Price, M. L. (1991). The subjective experience of foreign language anxiety: Interviewers with highly anxious students. In E. K. Horwitz and D. J. Young (Eds.), Language anxiety: From theory to research to classroom implications (pp. 101-108). New Jersey: Prentice Hall.

Rachman, S. (1998). Anxiety. Hove, East Sussex, UK: Psychology Press.

Saito, Y., Horwitz, E. K., \& Garza, T. J. (1999). Foreign language reading anxiety. The Modern Language Journal, 83(2), 202-218.

Scovel, T. (1978). The effect of affect on foreign language learning: A review of the anxiety research. Language Learning, 28(1), 129-142.

Sellers, V. D. (2000). Anxiety and reading comprehension in Spanish as a foreign language. Foreign Language Annals, 33(5), 512-521.

SHI, Y, Z., \& LIU, Z, Q. (2006). Foreign language reading anxiety and its relationship to English achievement and gender. Journal of PLA University of Foreign Languages, 29, 59-65.

Spielberger, C. D. (1972). Anxiety as an emotional state. In C. D. Spielberger (Ed.), Anxiety: Current trends in theory and research (Vol. 1, pp. 3-19). New York: Academic Press.

Spielmann, G., \& Radnofsky, M. L. (2001). Learning language under tension: New directions from a qualitative study. The Modern Language Journal, 85(2), 259-278.

Subaş1, G. (2010). What are the main sources of Turkish EFL students' anxiety in oral practice? Turkish Online Journal of Qualitative Inquiry, 1(2) 29-49.

Tsiplakides, I., \& Keramida, A. (2009). Helping students overcome foreign language speaking anxiety in the English classroom: Theoretical issues and practical recommendations. International Education Studies, 2(4), 39-44.

VanPatten, B., \& Glass, W. (1999). Grammar learning as a source of language anxiety: A discussion. In D. J. Young (Ed.), Affect in foreign language and second language learning: A practical guide to creating a low-anxiety classroom atmosphere (pp. 89-105). Boston: McGraw-Hill College.

Vogely, A. J. (1998). Listening comprehension anxiety: Students' reported sources and solutions. Foreign Language Annals, 31(1), 67-80.

Williams, K. E., \& Andrade, M. R. (2008). Foreign language learning anxiety in Japanese EFL university classes: Causes, coping, and focus of control. Foreign Language Teaching, 5(2), 181-191.

Young, D. J. (1990). An investigation of students' perspectives on anxiety and speaking. Foreign Language Annals, 23(6), 539-553.

Young, D. J. (1991). Creating a low-anxiety classroom environment: What does language anxiety research suggest? The Modern Language Journal, 75(4), 426-439.

Young, D. J. (Ed.). (1999). Affect in foreign language and second language learning: A practical guide to creating a low-anxiety classroom atmosphere (pp. 216-237). Boston: McGraw-Hill College.

ZHAO, N. (2007). A study of high school students' English learning anxiety. The Asian EFL Journal, 9(3), 22-34. 